A F R I C A N M I L I T A R Y S T U D I E S ・ Volume 3

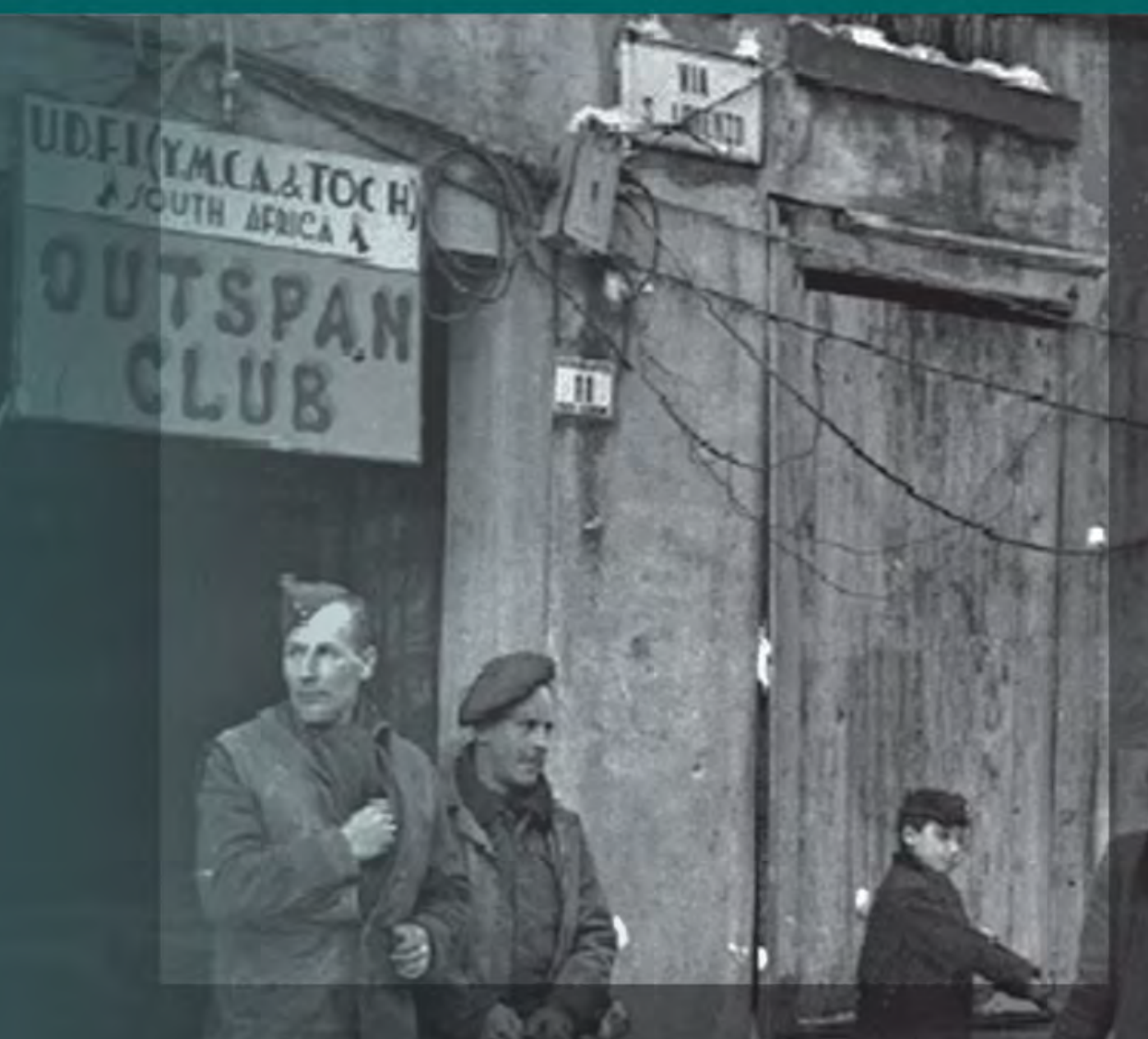

Sights, Sounds,

Memories

South African Soldier Experiences

of the Second World War 


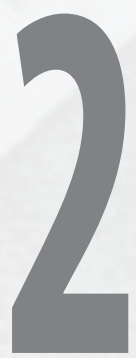

\section{SAVING PRIVATE LUGG}

\section{Carl Punt}




\section{INTRODUCTION}

One of the most popular and successful Hollywood war movies of all time, Saving Private Ryan, was released in 1998. It opens with James Ryan visiting a war cemetery many years after the war. He breaks down in tears at the sight of a gravestone while his family stands near him. He is overcome with grief. The narrative then goes back in time to the D-day invasion of Normandy on 6 June 1944. Captain Miller, who commanded a stick of the $2^{\text {nd }}$ US Ranger Battalion, of the $29^{\text {th }}$ Infantry Division, was tasked to find Private James Francis Ryan and bring him back home safely. Ryan, a paratrooper in the $101^{\text {st }}$ Airborne Division, was presumably somewhere in German-occupied France after their unit had missed their planned drop zone. Ryan was the youngest of four brothers who were all in the United States armed forces and had been fighting somewhere on a warfront. However, as things transpired, all three of James's brothers had been killed in action and their mother was to receive near concurrent notification of their deaths. The United States Army Chief of Staff, George C Marshall, decided that the grief would be too much for the mother to bear and authorised a rescue mission to bring James Francis Ryan home safely. ${ }^{1}$ Although much of the story is fictional, the mission led by Miller is based on a true set of events. The fictional Ryans were in fact the Niland brothers: Edward, Preston, Robert and Frederick. ${ }^{2}$ The movie portrays the horrors and reality of war in a very vivid way, allowing the audience to experience the war from a bottom-up perspective. In this way they could relate to the 'ordinary' soldier.

Saving Private Ryan is the inspiration for this chapter. There are striking similarities between the wartime experiences of the fictional James Ryan and the real-life main character here, Private John Beresford Lugg. Both men fought the Germans in Europe and at the same time, one in France, the other in Italy. Both had three brothers who were (presumed) killed in the war. Both were ordered back home because of these dramatic losses and the suffering of their families. And both 'made it home' to tell their story. In a wider sense, the chapter uses the Prince Alfred's Guard (PAG), the regiment in which Lugg served, as a lens through which to study the experiences of the 'ordinary' soldier in the Italian campaign. The reasons for enlistment, their military training, morale, the experiences of war and the war's impact on families are examined.

\section{HARRY LUGG AND HIS FOUR SONS}

On 22 February 1945 the Adjutant General, who was responsible for releases at the Union Defence Force (UDF) Administrative Headquarters in Pretoria, received the following heart-rending letter from a very concerned father: ${ }^{3}$ 
I had four sons in the Army.

My eldest joined the S.A.A.F. at the outbreak of the war. Early last year he was reported missing during a night bombing attack on Plovdiv in Bulgaria. After being kept in suspense for four months he was reported as a prisoner of war in Germany, and as far as I know he is still there, but we have not yet heard from him since October.

In December 1942 my second son was killed while serving as an air pilot in the S.A.A.F. as the result of a flying accident in the Sudan.

On the $15^{\text {th }}$ of last month my third son who had also joined the S.A.A.F. as an air gunner, was reported missing whilst engaged on a cross-country flight during the night somewhere in Palestine, and we have had no further news of him.

My fourth and youngest son is a private in the Prince Alfred Guards at the present with the $6^{\text {th }}$ Arm. Div. in Italy. His no. is 310599.

I am undergoing a serious operation on Monday, and my wife is far from well. I have written to the O.C. Prince Alfred Guards asking him to transfer my son to some base job, but I have since been advised to address you on the matter also. I accordingly do so in the hope that you will be [in] a position to relieve in some measure our present state of worry and anxiety.

I was formerly Chief Native Commissioner for Natal.

Yours faithfully,

(Sgt). H.C. Lugg. ${ }^{4}$

A clearly overwhelmed and anxious father begged the UDF to somehow assist in keeping his (perhaps last living) son safe from danger. He and his wife experienced what all parents who have children fighting in a war fear the most: death and uncertainty. One can only imagine how the Luggs must have felt when they heard that their eldest son had been taken prisoner at the hands of the Germans. Not knowing how he is treated, and how the Germans would behave as the tides of defeat were slowly rising over the German empire. Has his 'strong' personality been causing trouble for him? Eric, who matriculated from Maritzburg College in 1934, was described by his headmaster: 'He has individuality and can hold firmly to his opinion; he is not easily led or persuaded but is entirely honest and straight-forward' ${ }^{5}$ Eric was 24, single and working as a clerk when he joined the Active Citizen Force on 28 June 1938. ${ }^{6}$ Little did he know that South Africa would be dragged into a war little more than a year later. He joined the South African Air Force (SAAF) and started his Pupil Pilot Training Course at Baragwanath in July 1938. ${ }^{7}$ The Officer Commanding the Air Training School reported on Eric's progress:

This pupil progressed slowly at first but improved during the latter part of the course. He is a safe pilot but his flying is not polished. Should make a good service pilot with more practice. A good type but a bit slow in the uptake. ${ }^{8}$ 
Another report reads:

Average pilot. Works hard and good type. ${ }^{9}$

One can only wonder if his 'unpolished flying skills' and 'average skills' would account for the accident that would later lead to his capture. Eric qualified as a pilot at the bottom of his class (' $\mathrm{B}$ ' section) and was commissioned as a Warrant Officer Class II, while the 'A' candidates were commissioned as second lieutenants. ${ }^{10}$ His training was limited. At the time of his appointment he had flown only 71 hours dual and 54 hours solo. ${ }^{11}$ He was trained as a bomber pilot on Junkers (JU 52) aircraft. ${ }^{12}$ The UDF had bought the Junkers with the intention of converting them into bombers. But, after converting them, they realised that the British bombs they would be using could not be used in German-style bomb bays. All the aircrafts had to be re-fitted to be used as bombers. ${ }^{13}$ This oversight brought the quality of the training of the bomber pilots, and the bay loaders, into question, as they were unable to practise their loading skills, targeting skills or perform coastal patrols. After his training he was posted to 13 Squadron at Waterkloof Air Station ${ }^{14}$ on 8 January 1941 and promoted to second lieutenant. As the UDF embarked on the East Africa Campaign, he was posted to Nairobi the following month where he would serve for almost a year. He made a few more transfers, to 3 Squadron in May 1941, 6 Squadron in July 1942, and finally to 178 Squadron in October 1942. During this time he was promoted to lieutenant. He received five medals during this service: the 1939-1945 Star, the Africa Star, the Italy Star, the War Medal 1939-1945, and the Africa Service Medal. Eric served in three campaigns: East Africa (February to December 1941), North Africa (September to December 1943) and Italy (January to March 1944). ${ }^{15}$ He was reported missing on 19 March 1944 when his airplane was shot down during a night bombing mission over Bulgaria. ${ }^{16}$ His parents were notified only on 25 March. ${ }^{17} \mathrm{He}$ was confirmed a prisoner of war (POW) on 14 June $1944 .{ }^{18}$ It is not clear exactly when his parents received news that Eric was prisoner, but one can only imagine the relief, mixed with anxiety and helplessness, that they must have felt when they did. At the time of writing the letter, Mr Lugg Senior did not know the whereabouts of his son, nor indeed if Eric would survive the war. Luckily he did, and was released from duty on 23 November $1945^{19}$ after being promoted to captain. ${ }^{20}$

The second son, Cyril Trevor Lugg, followed in his brother's footsteps by joining the SAAF at the age of 24. Before enlisting, he had worked, like their father, for the Department of Native Affairs. He started his journey in the SAAF by being posted as a pilot to 75 Air School in October 1942. He was moved to 23 Air School in June 1942. Unlike his brother, he was commissioned immediately as a second lieutenant, which suggests that he was a better pupil pilot. He was posted to the SAAF Base Depot, which suggests that he flew cargo planes. Cyril died on 11 December 1942 in a flying accident while serving in the Sudan. His aircraft burst into flames leaving no possibility of survival. The cause of the accident remains unclear, possibly leaving his 
parents with more questions than they had answers. During his service he received two medals: The War Medal 1939-1945 and the Africa Services Medal. ${ }^{21}$

Harry Durnford Lugg, the third son, enlisted on 29 June 1942 at the age of 23, but was discharged on 15 July 1942, only two months later. It is not clear why exactly he was discharged after such a short period. One possible reason is that he got married, as he initially indicated his next of kin as his father with his address in Durban. He re-enlisted on 9 June $1944^{22}$, but on this occasion he indicated his next to kin to be his wife, Dorothy Lister Lugg. ${ }^{23}$ Dorothy stayed behind on their farm in Ladysmith, Natal, where Harry was a farmer. Interestingly, Harry also changed jobs between enlistments, as he went from being a miner to a farmer, perhaps indicating that the farm had come through his wife. Like his brothers, Harry joined the SAAF, but unlike them, both pilots, he became an air gunner. ${ }^{24}$

The South African Defence Act (Act 13 of 1912 as amended) ${ }^{25}$ only allowed for Union troops to be deployed in defence of the Union. Very early in the war, the need for Union troops to be deployed to East Africa and further afield increased. Soldiers could thus at first only be deployed within Southern Africa, since technically service outside the political borders was not necessarily seen as being for the direct defence of the country. Therefore there was confusion as to the interpretation of the Defence Act. According to Major General Brink, there was no law that could force civilians to fight overseas. All civilians could only be forced to defend the Union and serve the country up to the Equator. ${ }^{26}$ The Office of the Commandant-in-Chief at Defence Headquarters in Pretoria clarified the Defence Act to all Commandants in a letter:

Subject to the provisions of this Act, every citizen shall be liable between his seventeenth and sixtieth year (both included) to render in time of war personal service in the defence of the Union in any part of South Africa whether within or outside the Union. ${ }^{27}$

The Prime Minister, Jan Smuts, realised that he needed to deploy troops outside the specified boundaries, but he could not, and would not, force them. Politically, South Africa's white society was deeply divided and Smuts could not afford to antagonize the anti-war camp further by enforcing conscription. He had to rely on volunteers to make up the required numbers. ${ }^{28}$ Smuts told the Senate:

If you want to defend this country, you will have to proceed a great distance to beyond it, and the question then arises how far beyond it. ${ }^{29}$

Smuts advocated for service anywhere in Africa. ${ }^{30}$ On 29 March 1940 a new service oath, known as the Africa or 'Red Oath', was introduced. All volunteers were required to take the oath of their free will. Union soldiers could then be deployed anywhere in Africa for 
the duration of hostilities. ${ }^{31}$ An orange flash was worn on the volunteers' shoulders in order to identify them. These flashes were commonly known as 'Red Tabs'. ${ }^{32}$

Harry re-enlisted on 10 June $1944 .{ }^{33}$ He signed the General Service Oath eleven days later, ${ }^{34}$ acknowledging that he was required to serve 'anywhere' for the duration of the war, with an additional service period of six months after the war had ended. ${ }^{35}$ Harry never got to serve that long as the airplane on which he was flying went down somewhere over the Mediterranean Sea, ${ }^{36}$ near the coast of Palestine, during a night flight on 15 January 1945. His airplane never returned and it is presumed to have crashed accidentally, as being dark it was unlikely that they were shot down over the ocean. The crew was never recovered and presumed dead. ${ }^{37}$

John Beresford Lugg was the fourth and youngest son. Following in his brothers' footsteps, he joined the UDF. He was then 21 years old. His personnel file tells us that he had blue eyes and brown hair and was of average build, measuring five foot ten inches (1,77 meters) and weighing 160 pounds (72,5 kilograms). After school John had worked in the building trade, before deciding to enlist. Unlike his brothers, not wanting to fly, John joined the Army and started his war journey as a gunner in the $4^{\text {th }}$ Heavy Battery of the South African Artillery (SAA) on 21 April 1942. He signed the General Service Oath on 29 June $1942^{38}$, only a week after the fall of Tobruk in which South Africa suffered terrible losses. The fortress had fallen in a battle that lasted little over 24 hours. Some 32000 Allied soldiers, including 12722 men of the $2^{\text {nd }}$ South African Infantry Division (2 Div), became Axis prisoners of war. Tobruk was the single largest military catastrophe suffered by the UDF. ${ }^{39}$ The reasons for the defeat at Tobruk are wide-ranging and complex. But, did the defeat and the drive for vengeance, perhaps motivate John to sign the General Service Oath? Less than a year later John would be transferred to the PAG, $6^{\text {th }}$ SA Armoured Division $(6$ Div) and eventually find his way into Italy.

\section{THE POLITICS OF VOLUNTEERING}

It is not clear why John or his brothers enlisted. What could possibly have motivated him to join a war that had been going on for nearly three years, and one in which South Africa just had 'mixed' successes? At the time of his enlistment, all three older brothers were still alive and well, flying all over Africa. Did his brothers influence his decision? Then why wait three years? Would he have changed his mind if he had waited another six months - when Cyril had died? One can surmise what made him and his brothers enlist. The list of possible reasons why men are willing to fight in war is nearly endless. Individual beliefs differ, which makes it difficult to determine baseline motivations. Like all other wars, the Second World War also provided its own specific motivating factors. According to Grundlingh, there are mainly three factors that can account for men to have volunteered: ideological, economical and personal. ${ }^{40}$ 
Two main ideological views stand out as main motivational reasons: 'South Africanism' and 'anti-Hitlerism'. Jan Smuts advocated that white South Africans should stand together in defence of a notion of 'South Africanism'. It emphasized voluntarism, co-operation, and consensus and harmony for the greater good of all. The National Party, the main opposition to Smuts's United Party, on the other hand, believed that Afrikaners should stand together, apart from English-speaking whites. There were many whites, including among the Afrikaners, who bought into this idea of 'South Africanism'. They wanted an inclusive South Africa. They also realised the importance of having strong political and economic ties with Britain. ${ }^{41}$ On 19 August 1940 Smuts had urged his supporters to work together in unity:

What worries me is not what is going to happen during this war, but what will happen after the war when we have to live together in this country. We must build up a spirit of peace. ${ }^{42}$

This call of duty to serve your country and fight against the evil of Nazi Germany would account for the enlistment of many men. According to Van der Waag, Englishspeaking white South Africans fought largely for 'King and country', an intermingling of family tradition, loyalty and patriotism. ${ }^{43}$ Overy is of opinion that 'hatred of Hitler and "Hitlerism" was the moral cement of the Allied war effort'. ${ }^{44}$ According to The Star (Johannesburg) of 12 August 1940:

The recruiting figures for this Province (Natal) have soared far above our expectations, particularly from last May. For this Herr Hitler was partly responsible. Whenever he did anything spectacular, recruits literally poured in. ${ }^{45}$

Could it be that the Lugg brothers, being white and English, were motivated by these notions? The Lugg family also had a history of war service dating back to the AngloZulu wars in the last decades of the nineteenth century. Moreover, according to Harry Lugg's autobiography, two of his brothers, Colonel AJ Lugg and Captain GE Lugg served during the Second World War. They were tasked to recruit a thousand Zulus for the Native Military Corps at the outbreak of the war in 1939. His other two brothers, CE Lugg and BK Lugg, had served in the Great War and in the Bambatha Rebellion of 1906. Although Harry Lugg never served in the military, he did have 41 years of service as a government official. ${ }^{46}$ Harry had joined the Natal Civil Service as a clerk on 5 December 1899, only three weeks after the Anglo-Boer War had broken out, and was transferred to the Native Affairs Office in $1902 .{ }^{47}$ Quite possibly Harry Lugg's sons enlisted from a strong sense of family tradition of service. It is equally possible that the oldest three joined the SAAF because of the recruitment campaign that appeared constantly in the local newspapers. One such news article reads: 'Air Power: The Key to Victory ... Let the SAAF train you ... The SAAF needs you'. ${ }^{48}$ 
Perhaps the Luggs were motivated by financial reasons? Military pay has a strong influence on first-term enlistment decisions. ${ }^{49}$ The socio-economic situation in South Africa was not great as the country was still experiencing a 'poor white problem' at the time. ${ }^{50}$ The Great Depression of the 1930s had left many men, especially Afrikaners, in a terrible financial situation. The farming industry was hit hard by low international prices. Demand for South African goods fell, which compelled companies to cut wages in order to avoid bankruptcy. Unemployment soared. A severe drought between 1931 and 1932 added to severe economic pressure. Many farmers went bankrupt ${ }^{51}$ and were forced to seek work in the cities. ${ }^{52}$ Did these factors perhaps influence Harry Junior's decision to quit farming and enlist? Furthermore, uneducated whites competed with the Coloured and African workforces for unskilled jobs. The general working wages were too low to support a quality lifestyle and there was no foreseeable end in sight. ${ }^{53}$ Perhaps John Lugg felt there was no future in the building industry and looked to the UDF as a prospect?

Personal reasons are difficult to determine as each soldier would, at some level, have a personal conviction about the war. According to Grundlingh, 'a sense of adventure, curiosity, and the opportunity of male camaraderie offered by war service, often coupled with a desire to escape domestic strife, were all reasons that prompted individuals to join. ${ }^{54}$ Roos is of opinion that some white volunteers enlisted because of 'pecuniary need, patriotism or peer pressure'. ${ }^{55}$ Some men may have enlisted because of their religious convictions. All four Lugg brothers had indicated on their enlistment forms that they were members of the Church of England. ${ }^{56}$ Although this does not prove that they were motivated to enlist because of their religious convictions, it highlights the idea that the Luggs were 'ordinary' men fighting for 'ordinary' reasons.

\section{PRIVATE JOHN LUGG IN EGYPT AND ITALY}

The story continues when John was transferred to the PAG on 18 February 1943. ${ }^{57}$ The PAG had a total strength of 876 officers and men in Italy. John was one of 59 men who were from Durban and Pietermaritzburg. ${ }^{58} \mathrm{He}$ was placed into B Squadron, ${ }^{59}$ most likely as a gunner, drawing on his experience and training in the South African Artillery. The PAG became one of the armoured regiments of the $11^{\text {th }}$ Armoured Brigade (11 Armd Bde), one of the brigades forming the $6^{\text {th }}$ South African Armoured Division (6 Div). The 6 Div was formed on 1 February 1943, ${ }^{60}$ shortly after the North African campaign had come to an end, and the focus had shifted to Europe.The 1 Div was disbanded and, taking fresh volunteers, reformed into 6 Div. The 6 Div would be an armoured division since it would require fewer men. The initial idea was to form two divisions but, because of manpower shortages, the plans had changed. ${ }^{61}$ The division consisted of only two brigades (11 Armd 
and the $12^{\text {th }}$ Motorised Infantry) instead of the usual three. ${ }^{62}$ A British brigade, the Guards Brigade, was added in Italy. Major General Evered Poole was appointed as the general officer commanding the division.

After 25 days of embarkation leave, ${ }^{63}$ the PAG was shipped from Durban on 19 April and arrived at Tewkif Bay, Egypt, on 30 April 1943. The eleven-day journey was uneventful. They were moved into Khatatba Camp, which was located midway between Alexandria and Cairo. ${ }^{64}$ Strict censorship rules applied at the camp and the men were not allowed to take photos of their journey. ${ }^{65}$ This may have been frustrating for the men, as it was also probably their first overseas trip and they were not allowed to photograph their adventure. Khatatba was their home for the next eight months, and the place where they received extensive training. Instructors, who were withdrawn from 1 SA Infantry Division while the latter was still in the line, awaited them so that training could start right away. ${ }^{66}$

According to official training guidelines, once the men were moved to the concentration area, the following programme had to be followed: during the first week men were settled in and units were organised. Non-Commissioned Officers (NCOs) and men were graded. Drilling took up much of the time. The training became more intensive during the second week. Night route marches were introduced. Weapons training started in the second week, with special reference given to visual training. The third week's programme focused on light machine gun training and elementary tactical training. During the fourth week, elementary tactical training continued. The goal was to achieve a reasonable standard of efficiency within the first month of training. ${ }^{67}$

The training also focused on various aspects of armoured warfare. ${ }^{68}$ It covered three broad aspects: basic training, unit training and formation training. ${ }^{69}$ Training first focused on individual skills and later progressed to combined armoured warfare. The armoured and motorised brigades were trained to operate in support of one another. Emphasis was laid on manoeuvre warfare. According to feedback given on a training exercise: 'It was emphasised that mobility and elasticity were necessary for proper functioning, ${ }^{70}$ The co-operation between the armour and the infantry was emphasised. The tanks' main goal was to flank and envelop the enemy, while the infantry and artillery had to destroy enemy positions. ${ }^{71}$ Armour and infantry should fight as a combined arm in order to maximise their power and effectiveness. ${ }^{72}$ Manoeuvrability was essential to achieve victory, as echoed by German General Heinz Guderian: 'Only movement brings victory ...'73

As a gunner John Lugg had received somewhat limited practical experience on the rifle range. During a typical shooting exercise on 4 March 1943 each troop received the following ammunition: eight rounds anti-personnel, ten rounds high explosive (HE), only twenty-five rounds of .50 calibre Browning, and only four rounds of .30 calibre 
(which hardly even qualifies as a short burst with a machine gun!). To practise attacking, each troop received four rounds of anti-personnel ammunition, while the anti-tank guns got four rounds of HE and one smoke-generating round. Troop withdrawals were practised under the cover of smoke and two 2 -inch mortars provided cover. Simulated Infantry was engaged with co-axle guns (two belts of .30 calibre Browning). To practise engaging enemy tanks on the move, four $75 \mathrm{~mm}$ rounds were provided. The commanding officer emphasised that this might have been the last chance to shoot on the rifle range ${ }^{74}$ an indication that ammunition was very limited. In a progress report for June 1943, 12 Mot Bde HQ highlighted a lack of certain equipment. It lacked Vickers machine guns, mortars, general training equipment, attack guns, sufficient targets, even blackboards. The shortage of these materials delayed progress made on especially range work. ${ }^{75}$

A few months later a series of combined training exercises were held to put the division's skills to the test. These included exercises at Zonderwater, Cape Town, Durban, Pretoria, Florida, Tussle and Standerton. ${ }^{76} 11$ Armd Bde had a central role to play in Exercise Zonderwater, which took place from 28 to 31 December. The general idea was to simulate an anticipated attack by the enemy, whose intention was to breach certain key points and to advance all the way to Cairo. 6 Div would anticipate this move by attacking the enemy's left flank and cut its communications between Alexandria and Cairo. ${ }^{77}$ Some of the key objectives for 11 Armd Bde were to control night movement; maintain wireless silence; maintain traffic control through mine fields; deliberate attack by the whole brigade; mopping up the ground that they have dominated, but not to overrun it; the rapid occupation of battle positions; the distribution of anti-personnel and $105 \mathrm{~mm}$ fire; the protection of the nearby harbours; applying anti-gas measures; the withdrawal and protection of echelons from an armoured attack; crossing a defile in contact; to do reconnaissance in order to plan a counter-attack; and to practise a deliberate counter-attack. ${ }^{78}$ Each unit within 11 Mot Bde had its own umpire. Lieutenant Colonel NP Comrie acted as the umpire for PAG. The umpires had to indicate targets such as attack guns, machine guns, infantry and tanks. These targets were indicated by using different colour flags. Certain safety precautions were put in place to ensure no accidents happened. Tanks and artillery were given limited time-slots to practise range work, and live firing was limited to an area called Gebel Mreir. The umpire had to wear white armbands, for what it was worth. ${ }^{79}$ Unfortunately, an accident did occur during an exercise when an artillery shell fell short of its intended target and killed Sergeant PA Woodward (SA Medical Corps) and Private W Worral (FC/CTH) on 6 December. ${ }^{80}$ Such accidents would surely have left the men with emotions of fear, regret, anger and resentment, and a sense of the reality of what they were doing and preparing for.

On 29 December 11 Armd Bde simulated an attack on Gebel Mreir using live ammunition. Their task was to attack the position and dominate it until reinforcements from 12 Mot Bde could arrive. The enemy position was simulated as being held by 
a force equivalent to a battalion group. They also had protective minefields, attack guns, machine guns and infantry. There were no simulated enemy tanks, ${ }^{81}$ giving an armoured unit such as PAG limited training experience. Exercises such as Zonderwater provided the men with valuable training. It did not, however, prepare them for the action that awaited them in Italy. ${ }^{82}$ Unlike Italy, the desert is flat and had very few built-up areas. The topography of the desert favoured mechanized warfare based on a war of manoeuvrability. ${ }^{83}$ The topography of Italy differed very much from that of the desert. German Field-Marshal Erwin Rommel once noted:

It is only in war in the desert that the principles of armoured warfare as they were taught in theory before the war could be fully applied and thoroughly develop. It was only in the desert that real tank battles were fought by large-scale formations. ${ }^{84}$

Due to the extremely mountainous nature of the terrain in Italy, manoeuvre warfare could not be implemented. The hills, mountains and rivers made it impossible to execute flanking manoeuvres. The terrain also favoured the Germans in defence. ${ }^{85}$ British Field Marshal Sir Harold Alexander described the geographical situation in Italy as follows:

The Allied armies were to be faced with a seemingly unending succession of difficulties of terrain - as Winston Churchill remarked, there was 'always something else'; they were to be called upon to fight with resources always inadequate to their tasks; and they were to experience a 'savage versatility' of climate without any parallel in northwest Europe. The axis of any advance northward invariably lay across natural obstacles of rivers or mountains; and, because German demolitions were so efficient and effective, a small rear-guard could always put up a fierce battle while the main body went back at its leisure. ${ }^{86}$

Between 21 and 22 January 1944 the Division was moved to a new training area at Helwan in Egypt. The focus of the training changed. More focus was placed on training in close country and river crossings. Unfortunately, the terrain in Egypt made realistic training impossible. 6 Div HQ received a disturbing report from British forces in Italy. The report indicated that the trained armoured movements of "encounter and deliberate battles' were useless in Italy as the broken terrain prevented such movements. Visibility caused another headache as the Germans were well camouflaged. ${ }^{87}$ Although the tank crews of 11 Armd Bde were trained to engage fortified positions, they were also trained how not to be tied down and become vulnerable to enemy fire. Armour assaults against well-developed defensive positions are often suicidal and should be avoided. ${ }^{88}$ The average engagement in Italy occurred at 70 metres. Concealed antitank guns destroyed British tanks before they were spotted. The only way to take on the well-developed German defences was to plan attacks well in advance and to do proper reconnaissance. The British emphasised the importance of good infantry-tank cooperation. The training 6 Div received lacked practical infantry-tank co-operation. Captain JC Brand, PAG, shared his experience: 
Our training was basically technical ... we learned not much more than how to use our weapons and equipment ... how a tank operates in a troop, how a troop operates in a squadron and the basic rules of tactics which apply in tank operations (and for that matter in infantry operations as well) ... We were introduced to infantry co-operation, especially as it was appreciated that the large-scale tank battles, as much, in a theatre like Italy, were likely to be the exception rather than the rule. But to be proficient in that department would have required considerably more training, practice and experience that we took into Italy in 1944. I remember, for example, being bothered by the question of when would an operation be tanks with infantry support under tank command or infantry with tank support under infantry command and who would make those decisions. ${ }^{89}$

Special lectures were given on German army organisation, weapons and tactics, ${ }^{90}$ but these were academic in nature, and were of limited value since the practical training that 6 Div had received to this point did not fully prepare them for what awaited them in Italy.

The Division was finally sent to Italy and embarked from Alexandria between 14 and 16 April 1944. ${ }^{91}$ PAG arrived in Italy on 20 April at the port of Taranto. The sight of the Italian countryside was a novel experience to the men. The beautiful mountainous scenery was in great contrast to the flat and featureless desert that the men had become used to. They had finally reached a theatre of war after months of training. ${ }^{92}$ Lieutenant Armstrong described the disembarkation as:

A hectic period of preparation, concentration, and the final journey towards the battle line. ${ }^{93}$

The mountainous country was ideally suited for defensive warfare. The positions were manned by a skilful and stubborn enemy who would have to be driven out by hard fighting. ${ }^{94}$ Major fighting for the South Africans began at Cassino, where the Germans under the leadership of Field-Marshal Kesselring had constructed the formidable Gustav Line. Allied soldiers eventually took the town of Cassino, while the Germans held the high ground and an ancient abbey on the heights of Monte Cassino. The abbey was bombed under orders of General Mark Clark and ironically made the breaching of the Gustav Line more difficult as the Germans used the debris as cover. Lieutenant AB Colenbrander, troop commander of A Squadron PAG, describes the scene as follows:

The whole Abbey was in ruins. At the bottom of the crater a priest was conducting a service in Latin. The ruins were still smouldering and there was an all-pervading smell of explosives and burning ... Everyone was caught in the awesomeness of the moment, each with his own thoughts on the senselessness of war - humble before God. ${ }^{95}$ 
Eventually the Line was broken through and the advance to Rome could continue. ${ }^{96}$ Rome was reached on 6 June. At this time 6 Div fell under command of the $8^{\text {th }}$ Army. 11 Armd Bde formed the spearhead of the Division as it passed though Rome. Field Marshall Alexander remarked:

South Africans are the spearhead of the advance, and will remain the spearhead.

PAG and Special Service Battalion (SSB) fought its way forward to Celleno. During the Battle for Celleno PAG was deployed without infantry support and lost five tanks to German anti-tank guns. Three of the five tanks belonged to Lieutenant AB Colenbrander's A Squadron. Captain Brand reports:

I remember witnessing the destruction of three of Colenbrander's tanks ... We came under anti-tank fire and had to do very hasty retreat in reverse gear ... I believe that it was during this time, i.e. while we were still moving eastwards, that I watched helplessly as Collenbrander's three tanks were hit one after the other ... by $88 \mathrm{~mm}$ fire...

Captain Brand blamed the losses on the lack of infantry support:

We (PAG) should certainly have had infantry ... as the S.S.B. had had ... Why the Scots Guards were not committed with the PAG on the day I cannot say... ${ }^{97}$

Three days later PAG experienced more losses to anti-tank fire. Sergeant LA Green, C Squadron, recalls:

We were on a dirt road and came to a corner when the road collapsed and the track was pulled off. Cpl Foote managed to pass me and about 25 yds further on the same thing happened to him. No. 1 troop (under command of Lieutenant JGVenter) ... was told to take over from us (No. 2 troop) and didn't get very far before an $88 \mathrm{~mm}$ shot killed him and his gunner. That shot would have been for me if my track didn't pull off? ${ }^{9}$

Despite heavy rain, the division pushed forward to the Trasimeno Line. Here, at Chiusi, the Division came up against a battalion of the Hermann Goering Division, one of Germany's most formidable armoured units. First City/Cape Town Highlanders (FC/ $\mathrm{CTH}$ ), an infantry regiment within 12 Mot Bde, took a heavy beating and failed to take Chiusi. The town eventually fell and the push forward continued. The next strong point they had to face was the Hilde Line. Heavy fighting for the mountains and the ridges overlooking Florence followed. Florence was entered by 11 Armd Bde on 4 August. To that date the division had suffered a total of 2100 casualties. After a few days of rest, the division pushed forward to the Gothic Line, a vast defensive line in the Apennines. The division was put under the command of General Clark's $5^{\text {th }}$ Army. Fierce fighting took place at Mt Alto and Mt Porro del Bagno. The enemy had been 
enforced and was determined to oppose the Allied advance. The weather did not play along as cold rains and piercing winds added to the misery. ${ }^{99}$ A South African Press Association (SAPA) correspondent commented:

More rain, sloshing mud, cold and mist have not deterred the South Africans and the Guardsmen from making further progress along their hardly-hewn path which aims down the backdrop of the Apennines toward Bologna. ${ }^{100}$

The road to Bologna had formidable ridges on both sides. It was there that the Division encountered the fanatical 16 SS Division. 11 Armd Bde pushed up the slopes of Mt Vigese and occupied it on 6 October. The South Africans fought hard, even in those terrible conditions:

In foul conditions - heavy rain and thick mud - the Natal infantrymen drove back German SS troops who resisted the advance. A good number of prisoners were taken. ${ }^{101}$

For days the South African forward troops have been living on exposed hill slopes, in slime-choked slit trenches, from which they have to bail water during drenching mountain downpours. In these conditions they have been subjected to a volume of artillery and mortar fire the like of which they have seldom encountered before." 102

Mt Stanco became the next objective. The Germans were well entrenched and covered by artillery. Because of the steep slopes 11 Armd Bde could not engage the enemy in an armoured assault. A Squadron PAG, together with A Squadron SSB, had to leave their tanks to be used as infantry. ${ }^{103}$ General Poole brought 12 Mot Bde to secure the position. The second largest set-piece attack by South African troops in the war (second to only Alamein) commenced and they succeeded in taking Mt Stanco. The battle for Mt Salvaro was an infantry affair. 11 Armd Bde provided support in the form of carrying supplies and casualty evacuation. B Squadron PAG also gave close artillery support. ${ }^{104}$ After taking the Salvaro feature, General Clark ordered the $5^{\text {th }}$ Army to consolidate along the line gained. Heavy snowfall and bitter cold made life miserable. ${ }^{105}$ Some restructuring took place and a third brigade, 13 Mot Bde, was added to 6 Div. 12 Mot Bde was ordered to take Mt Sole and Mt Caprara with the support of A Squadron PAG. Although successful, FC/CTH and Witwatersrand Rifles/ De La Rey Regiment (WR/DLR), also part of 12 Mot Bde, suffered 49 and 124 casualties respectively. ${ }^{106}$ A Squadron PAG lost ten of their thirteen Sherman tanks to mines. ${ }^{107}$ On 11 April Field-Marshall Alexander motivated his troops:

Final victory is near ... The moment has come for us to take field for the last battle which will end the war in Europe.${ }^{108}$

On 15 April the $15^{\text {th }}$ Air Force made its greatest effort of the Italian Campaign by dropping 1500 tons of bombs on targets ahead of the $5^{\text {th }}$ Army. ${ }^{109}$ A massive battle 
awaited the $5^{\text {th }}$ Army. It is important to note that John Lugg was removed from the front line on 16 April at a crucial point in the war when fighting was far from over. ${ }^{110}$

Although John's war was over, PAG still had a massive task ahead. After the enemy withdrew from Collina, 11 Armd Bde exploited the success. The enemy had been driven through the mountains onto the plains of the Po. PAG's tanks were ordered to secure an important bridge over the Panaro River. The enemy resistance was crumbling as Allied forces moved into the Po Valley. The armoured units reached Treviso by 30 April. The final push to Milan began. On route they heard news of the surrender of the German forces in Italy. ${ }^{111}$

Although fighting is the most dangerous part of a war, there are other dangers as well. Some of them were most unexpected. In a routine order in July 1944 Lieutenant Colonel Olsen warned PAG about the apparent dangers of Italian wine. Two interesting warnings were issued. The first stressed the high alcohol percentage of the average Italian wine: a litre of wine contained nearly as much alcohol as a pint (0,56 litre) of whiskey. Olsen also warned that drunkenness was the most common contributing factor to crime, and that drunkenness would not be accepted as an excuse for an offence. Perhaps more alarming, a member of the Div had died after purchasing wine from a private house. Soldiers were therefore ordered not to buy wine from unauthorised sources. The second warning was about the dangers of contracting malaria: 'more stringent anti-malarial precautions than ever before will be taken by all ranks, as the incidence of malaria in the Arno Valley is the highest in the world!" ${ }^{112}$ In a Routine Order by General Poole, soldiers were ordered not to bath in the Arno River as a number of cases of a severe form of infectious jaundice was reported after bathing in the river. ${ }^{113}$ If the Germans, Italian home-made wine or the mosquitoes did not kill you, bathing would! After more cases of wine and water poisoning occurred, soldiers were prohibited from visiting Italian bars, wine shops and restaurants. Soldiers were also not allowed to drink water from public wells and all water had to be chlorinated daily. ${ }^{114}$ Since John's hospital record in his personnel file is clean, we can accept that none of these 'dangers' got the better of him. ${ }^{115}$

A personal story about a war experience would not be complete without looking into the behaviour of the specific person. John Lugg is no different. Although the conduct assessment on his Record of Service indicates 'very good', John was not always 'well-behaved'. The first minor offence that John was punished for occurred on 25 September 1942. He was stationed in the Bluff, Durban as a gunner in the South African Artillery. John was punished for neglecting 'good order and military discipline' as his 'rifle was dirty'. The punishment was recorded as 'administered', perhaps indicating physical punishment of some kind. A month later John was punished for 'neglecting to obey standing orders during a state of emergency', for which he was 'confined to barracks for three days'. Spending Christmas in the military was not something John looked forward to. He went absent without leave (AWOL) on Friday 
25 December 1942. Unfortunately for him, he was apprehended the next day and was 'confined to barracks' for seven days as a result. On 9 February 1943 he was caught sleeping on duty and was 'confined to barracks' for three days. But being 'confined to barracks' did not discourage him from repeating this behaviour. He went AWOL again on 2 January 1944, this time in Egypt where he was receiving training as a member of PAG. He had to forfeit one day's pay as punishment. On 28 February 1944 he was given seven day's field punishment for breaking section 6(2)(4) of the Military Disciple Code (MDC). It is not clear what John did wrong, but the offence was severe enough that Lieutenant Colonel Olsen, CO of PAG, imposed the punishment in person, possibly suggesting that John's behaviour had to be made an example of. On 3 April 1944 John broke section 40 of the MDC ('conduct to the prejudice of good order to military discipline') for which he had to forfeit a week's pay. ${ }^{116}$ John embarked for Italy ten days later, on 13 April 1944. ${ }^{117}$ The 6 Div was shipped from Alexandria and Port Said between 12 and 16 April 1944. ${ }^{118}$ It seems that he pulled his act together, because there is no record of poor discipline after he was deployed to Italy.

In December 1944 Colonel Olsen, commanding officer of PAG, wrote to General Mark Clark, commanding officer of the $5^{\text {th }}$ US Army, under which 6 Div was deployed, a Christmas greeting letter. General Clark wrote back to Colonel Olsen on 24 December 1944. The problem with the letter was that he twice got the name of PAG wrong, calling it 'Prince Albert's Guard' instead of 'Prince Alfred's Guard'. This might be considered a honest mistake, but one can only imagine how Olsen, and the men of PAG, including John, must have felt when their commanding general did not even know their regiment's name! ${ }^{119}$

John received the following recommendations during his service: the 1939-1945 Star, the Africa Star, the Italy Star, the British Defence Medal, the War Medal 1939-1945, and the Africa Service Medal. ${ }^{120}$

If John's morale was low after spending his third consecutive Christmas in the army, it would soon improve. Unknown to him at the time, his father was about to write the transfer request. It is not clear if Lugg senior's request was acknowledged, as no official answer could be found. There are, however, a few clues that indicate that this might have been the case. The letter had made it all the way to the Adjutant General for Releases' office in Pretoria on 18 February 1945. This indicates that the officer commanding PAG had forwarded it to Pretoria for consideration and therefore had given the request his blessing. This office forwarded the request to UDF Admin HQ on 22 February, but no final outcome is on record. The original letter was found in the archives in a file marked 'Releases - Closed'. This file consists mainly of positive feedback granting releases, the granting of discharges and compassionate leave. There are many other files in the military archives that contain applications for compassionate leave. In one such file, for example, a total of 899 cases for release were applied for. Almost all the request were denied. ${ }^{121}$ We can assume that the correct steps were 
taken when applying for leave. In a detailed letter stipulating all the requirements for compassionate leave and releases, the Adjutant General instructed:

Applications for the release or discharge of UDF personnel usually originates in the Union. Such applications will ordinarily be dealt with by one of the tribunals depending on whether it is made by agriculture, commercial or industrial interests. The tribunal in such cases may make a recommendation in accordance with the application, or such other recommendation in variation thereof as they may think fit, not excluding a recommendation that the member be not discharged or released.

The normal procedure in cases where the members are serving up North will be to submit such applications for release etc. with the recommendation of the tribunal concerned, to you for consideration by the OC Formation concerned.

The above is the normal procedure which will be followed as a matter of routine but this should be noted that this HQ may in exceptional circumstances order the return to the Union of any member serving in the field without reference to any other authority. ${ }^{122}$

John was sent back to the Union on 16 April and was discharged from the army on 14 July $1945 .{ }^{123}$ The last time John's name appears on the regimental nominal roll is on 31 March. ${ }^{124}$ The German Army in Italy surrendered only on 2 May, about two weeks after John had been sent home. PAG fought until 9 May, when Germany surrendered. Small groups of PAG were leaving for South Africa for demobilisation only on 25 May. ${ }^{125}$ This indicates that not only was Lugg Senior's request to keep John safe acknowledged, but that it was decided to release John from service at a time when the war was still in full swing.

\section{CONCLUSION}

The UDF casualties in Italy totalled 5 176, of whom 753 were killed. ${ }^{126}$ PAG suffered a loss of 25 killed, 283 wounded and 7 missing. ${ }^{127}$ Although it is a small number compared to the 4124 South Africans who were killed during the entire war, ${ }^{128}$ it is a great loss in its own right.

The Lugg family suffered greatly after the loss of Cyril and Harry. When John made it through the war, his parents must have been ecstatic. Little did they know at the time that six months later they would also be reunited with Eric. The war had left a permanent mark on this family. In his autobiography, A Natal Family Looks back, Harry Lugg makes no reference to his sons' war experiences and sacrifices. Perhaps the memory was too painful to share. He ends the book with:

Our Family has witnessed, from small beginnings, the phenomenal development of this country during the last hundred years, and has been privileged to 
contribute in a small way to this achievement. May the experiences recorded here help a later generation to understand the significance of the past. ${ }^{129}$

The Luggs have made their contribution to this country. Harry Lugg passed away in 1978 at the age of $95 .{ }^{130}$ He would not suffer the pain of losing another child. Apart from his four sons, Harry also had two daughters. The eldest, Phyllis Sheila, passed away in 2000 at the age of 75. ${ }^{131}$ The youngest, Eva Nancy, passed away in 2017 at the age of $89 .{ }^{132}$ Both Eric and John returned home and reached an old age. Eric passed away in 2005 at the age of $89,{ }^{133}$ John in 2007 at the age of $87 .{ }^{134}$ 


\section{Endnotes}

1 Plot summary of Saving Private Ryan

[Retrieved 17 October 2019] www.imdb.com/title/tt0120815/plotsummary

2 J Elphick, The Real Life Story Behind Saving Private Ryan

[Retrieved 17 October 2019] www.gijobs.com/the-real-life-story-behind-savingprivate-ryan/

3 Harry Lugg to Adjutant General, 22 Feb 1945, Divisional Documents (Div Docs), box 183, file AQ 18/9, vol 7, Releases-closed, Department of Defence Archives, Pretoria (DODA).

4 Harry Lugg to Adjutant General, 22 Feb 1945, Divisional Documents (Div Docs), box 183, file AQ 18/9, vol 7, Releases-closed, DODA.

5 Testimonial by Headmaster, War Records (WR), Personnel File: ED Lugg no 47785, DODA.

6 Attestation form of Coast Garrison and Active Citizen Forces, Department Contract of Defence Service Contract for ED Lugg, WR, Personnel File: ED Lugg no 47785, DODA.

$7 \quad$ Pupil Pilot's Course Commencing 1 July 1938, no W. 61/22/7/6, WR, DODA.

8 Report by OC of Air Training School, WR, Personnel File: ED Lugg no 47785, DODA.

9 Report by OC of Air Training School, WR, Personnel File: ED Lugg no 47785, DODA.

10 Qualification- SAAF Flying Badge:1-2, WR, Personnel File: ED Lugg no 47785, DODA.

11 WR, Personnel File: ED Lugg no 47785, DODA.

12 WR, Personnel File: ED Lugg no 47785, DODA.

13 JA Brown, A Gathering of Eagles, South African Forces, World War II, Volume II (Cape Town: Purnell, 1970), p 23.

14 Statement to be completed in the case of Candidates for Commissioned Rank in the Union Defence Force: 2, WR, Personnel File: ED Lugg no 47785, DODA.

15 Record of Volunteer's Service: 1,WR, Personnel File: ED Lugg no 47785, DODA.

16 Application for appointment, WR, Personnel File: ED Lugg no 47785, DODA.

17 Notification that an Officer or Soldier has been reported missing, recorded 12 April 1944; and Repatriated Ex PW Service Record Serial no R824, WR, Personnel File: ED Lugg no 47785, DODA.

18 Application for appointment, and Telegram to War Pay Department by Adjutant General Hay, 26 June 1944,WR, Personnel File: ED Lugg no 47785, DODA.

19 Release from service letter, Ref. E3/47885V; and Release certificate, Document 17B, WR, Personnel File: ED Lugg no 47785, DODA.

20 Note by Adjutant General JP Marais, Document 18, WR, Personnel File: ED Lugg no 47785, DODA.

21 WR, Personnel File: CT Lugg no 206215, DODA.

22 WR, Personnel File: HD Lugg no 607798, DODA.

23 Marriage Record,WR, Personnel File: H.D. Lugg no 607798, DODA.

24 WR, Personnel File: H.D. Lugg no 608898, DODA.

25 A Wessels, 'The first two years of war:The development of the Union Defence Forces (UDF) September 1939 to September 1941', Military History Journal, vol. 11, no. 5 (2000). 
Letter from Pretorius to Venter, DF Malan Collection, file 1/1/1579, Stellenbosch University Archive (SU).

Letter from the Commandant-in-Chief, Burger Commando's, Defence Headquarters, DF Malan Collection, file 1/1/1579, SU.

A Grundlingh, 'The King's Afrikaners? Enlistment and ethnic identity in the Union of South Africa's Defence Force during the Second World War, 1939-45', Journal of African History, vol. 40 (1999), p 354; UWH, Box 249, Troops for overseas: Only Volunteers for North, DODA; I van der Waag, 'The Union Defence Force Between the Two World Wars,1919-1940', Scientia Militaria, vol. 30, no. 2 (2000), pp 201-202.

GC Olivier, 'Die grondslae van Suid-Afrika se buitelandse beleid' (University of Pretoria: PhD thesis, 1973), p 212.

van der Waag, 'The Union Defence Force Between the Two World Wars,1919-1940', p 214 .

B Nasson, South Africa at War, 1939-1945 (Sunnyside: Jacana, 2012), p 92; "PER ASPERA" or the birth of South Africa's Army 1939/1940, p 6, JC Smuts Collection, box 143, file 137, National Archive of South Africa, Pretoria (NASA).

JAI Agar-Hamilton and LCF Turner, The Sidi Rezegh Battles (Cape Town: Oxford University Press, 1957), pp 72-73; G Bentz, 'Fighting Springboks, C Company, Royal Natal Carbineers: From Premier Mine to Po Valley' (Stellenbosch University: MMil thesis, 2013), pp 14-15.

Regimental Conduct Sheet, WR, Personnel File: HD Lugg no 607798, DODA. WR, Personnel File: HD Lugg no 607798, DODA.

War diary, 10 Feb 1943, War Diaries (WD), Box 76A, file 22, First City, 1 Jan 1943 to 31 Mar 1943, DODA.

Application for Campaign Medals (1939 onwards), WR, Personnel File: H.D. Lugg no 607798, DODA.

WR, Personnel File: HD Lugg no 607798, DODA.

Squadron, Troop, Battery, and Company Conduct sheet, WR, Personnel File: JB Lugg no 310599, DODA.

JAI Agar-Hamilton and LCF Turner, Crises in the desert (Cape Town: Oxford University Press, 1952), pp 160-161, 214; R Collier, The War in the desert (Virginia:Time-Life Books Inc., 1977), p 92; WK Hancock, Smuts: The Fields of Force, 1919-1950 (London: Cambridge University Press, 1968), p 375.

Grundlingh, 'The King's Afrikaners?', pp 359-362.

Grundlingh, 'The King's Afrikaners?', p 359.

'Testimony of loyalty from 11,500 Women Presented to Premier', Rand Daily Mail, 20 August 1940, Union War Histories (UWH), box 278, DODA.

3 I van der Waag, 'South African Manpower and the Second World War'. In: Douglas E Delaney, Mark Frost, and Andrew L Brown, eds. Military Manpower and the British Empire 1939-1945 (Ithaca: Cornell University Press, forthcoming 2021).

R Overy, Why the Allies won (London: Jonathan Cape,1995), p 286.

'Lip Loyalty Denied', The Star (Johannesburg), 12 August 1940.

HC Lugg, A Natal Family Looks back (Durban:TW Griggs \& Co., 1970), p 125.

Harry Camp Lugg Papers, Killie Campbell Collections, University of Kwazulu-Natal [14 May 2020] http://campbell.ukzn.ac.za/?q=node/22105

'Air Power:The Key to Victory', The Natal Witness (Pietermaritzburg), 21 March 1944. 
49 CR Roll and JT Warner, 'The Enlisted Career Manpower in the All-Volunteer Force'. In:W Bowman, R Little and GT Sicilia, The all-volunteer Force after a decade, Retrospect and Prospect (Washington: Pergamon-Brassey's International Defence Publishers, 1983), p 61.

50 H Giliomee, The Afrikaners: Biography of a people (Cape Town: Tafelberg, 2003), p 315.

51 'Aan diegene van my kiesers wat dink', DF Malan Collection, file 1/1/1432, SU; Neil Roos, Ordinary Springboks: White Servicemen and Social Justice in South Africa, 1931-1961 (London: Ashgate, 2005), pp 13,19-20.

52 AM Fokkens, 'Afrikaner Unrest within South Africa during the Second World War and the measures to suppress it', Journal for Contemporary History, vol. 37, no. 2 (2012), p 124.

53 Roos, Ordinary Springboks, p 14; Debatte van die Volksraad, 26 May 1939, DF Malan Collection, file 1/1/1579, SU.

54 Grundlingh, 'The King's Afrikaners?', p 362.

55 Roos, Ordinary Springboks, p 34.

56 See personnel files of the Lugg brothers.

57 Nominal Roll, WD, Box 394, Prince Alfred's Guard, 1 February 1944 to 29 February 1944, DODA; Record of Volunteer's Service, WR, Personnel File: JB Lugg no 310599, DODA.

58 Orpen, Prince Alfred's Guard, p 286.

59 Nominal Roll - Embarkation, WD, box 394, Prince Alfred's Guard, 1 April 1944 to 31 April 1944, DODA.

60 N Orpen, Victory in Italy (Cape Town: Purnell, 1975), p 4.

61 E Kleynhans, 'The First South African Armoured Battle in Italy during the Second World War:The Battle of Celleno - 10 June 1944', Scientia Militaria, vol. 40, no. 3 (2012), p 251.

62 W Steenkamp, The Black Beret: The history of South Africa's' Armoured Forces, Volume 2: The Italian Campaign 1943-1945 and Post-War South Africa 1946-1961 (Solihull: Helion \& Company Limited, 2017), p 35.

63 Document 9682, UWH, box 152, Units and formations, History of Prince Alfred's Guard (PAG), 1856-May 1943, DODA.

64 WR, Personnel File:JB Lugg no 310599, DODA; N Orpen, Prince Alfred's Guard, 1856-1966 (Cape Town: Books of Africa, 1967), p 175.

65 Routine Order no 8/44, WD, box 394, Prince Alfred's Guard, 1 Mar 1944 to 31 Mar 1944, DODA.

66 Document 6314, UWH, Special Narep Collection, CFM 4: 6302-6422, Italian Campaign, 6 SA ARMD DIV (dated 25 Mar 44), DODA.

67 History of organisation + training 4 infantry + armour by Mayor E. Nillan, SAA, pp 24-27, UWH, box 151, DODA.

68 The Story of the Sixth South African Armoured Division, p. 3, UWH, box 140, DODA; Kleynhans, 'First South African Armoured Battle in Italy', p 253.

69 Eric Axelson, Trg. History of 6 S.A. Armd Div, April 1944, UWH, box 140, DODA; document 6315, Special Narep Collection, CFM 4: 6302-6422, Italian Campaign, 6 SA Armd Div, 25 Mar 1944, DODA.

War diary, 2 January 1944,WD, box 394, Prince Alfred's Guard, 1 Jan 1944 to 31 Jan 1944, DODA.

71 Kleynhans, 'First South African Armoured Battle in Italy', pp 252-256.

72 'South Africa's Sixth Division', p 1, UWH, box 141, DODA.

73 R de Vries, C Burger and W Steenkamp, Mobile Warfare for Africa, Volume 1 (Solihull: Helion \& Company Limited, 2017), p 117. 
74 War diary, 4 Mar 1944,WD, box 394, Prince Alfred's Guard, 1 Mar 1944 to 31 Mar 1944, DODA.

75 Progress report for period ended 5 Jun 1943, WD, box 367, War Diary of HQ 12 Mot Bde, 1 Jun 1943 to 30 Jun 1943, DODA.

76 See Div Docs, box 202 for details.

77 Exercise "Sonderwater", 6 SA Armd Div Exercise Sonderwater, Div Docs, box 202, DODA.

78 Exercise "Sonderwater", General Instructions (control and umpires), Div Docs, box 202, DODA.

79 Exercise "Sonderwater", General Instructions, Div Docs, box 202, DODA.

80 J Bourhill, Come back to Portofino: Through Italy with the 6th South African Armoured Division (Johannesburg: 30 Degrees South, 2011), p 77.

81 Exercise "Sonderwater", Time table and Umpire notes, Div Docs, box 202, DODA.

82 'South Africa's Sixth Division', UWH, box 141, file Narep 5, DODA.

83 Katz, South Africans vs Rommel, p 88.

84 Agar-Hamilton and Turner, Crises in the desert, pp 1-2.

85 Anon., 'SA Forces in the Second World War, Union Defence Force: Land forces', Militaria, vol. 19, no. 3 (1989), p 35; A Beevor, The Second World War (New York: Little, Brown and Co., 2012), pp 530, 532.

86 JL Keene, South Africa in World War II, A Pictorial History (Cape Town: Human \& Rousseau, 1995), pp 179-180.

87 JJ Bruwer, 'Die rol van die Sesde Suid-Afrikaanse Pantserdivisie in Italië: 27 Mei tot 4 Augustus 1944' (Randse Afrikaanse Universiteit: PhD thesis, 1989), pp 43-46. Steenkamp and Heitman, p 29.

89 Bruwer, 'Die rol van die Sesde Suid-Afrikaanse Pantserdivisie in Italië', pp 45-46.

90 War diary, 1 Mar 1944, WD, box 394, Prince Alfred's Guard, 1 Mar 1944 to 31 Mar 1944, DODA.

91 Orpen, Victory in Italy, p 25

92 Orpen, Prince Alfred's Guard, pp 185, 187.

93 Lt Armstrong, "The story of the "Sixth", UWH, Special Narep collection, file CFM 3, DODA.

Year Book Article (Year Book no 23-1946- Chap xxx), p 23, UWH, box 169, Narep UNFO 24, DODA.

95 GH Hobbs, From Sicily to the Alps (Claremont: Mallard Publishers, 1999), pp 95-96.

96 Steenkamp, The Black Beret, pp 55-56.

97 Bruwer, 'Die rol van die Sesde Suid-Afrikaanse Pantserdivisie in Italië', pp 157-158.

98 Bruwer, 'Die rol van die Sesde Suid-Afrikaanse Pantserdivisie in Italië', pp 176.

99 Year Book Article (Year Book no 23-1946- Chap xxx), pp 23-29, UWH, box 169, Narep UNFO 24, DODA.

100 'Sloshing in Mud; With the Sixth SA Armoured Division', The Natal Witness, 24 October 1944.

101 'Natalians Drive Back German SS Troops', The Natal Witness, 9 October 1944.

102 'Springboks battle in slime-choked Slit Trenches', The Natal Witness, 25 October 1944.

103 Steenkamp, Black Beret, p 217.

104 Steenkamp, Black Beret, pp 228-229. 
105 Year Book Article (Year Book no 23-1946- Chap xxx), pp 26-29, UWH, box 169, Narep UNFO 24, DODA.

106 Year Book Article (Year Book no 23-1946- Chap xxx), pp 26-29, UWH, box 169, Narep UNFO 24, DODA.

107 Hobbs, From Sicily to the Alps, pp 214-215.

108 Orpen, Prince Alfred's Guard, pp 270-272.

109 Orpen, Prince Alfred's Guard, pp 270-272.

110 WR, Personnel File: JB Lugg no 310599, DODA.

111 Year Book Article (Year Book no 23-1946- Chapter xxx), pp 29-30, UWH, box 169, Narep UNFO 24, DODA.

112 Routine Order no 21/44, 30 July 1944, WD, box 638, Prince Alfred's Guard, 1 Apr 1944 to 30 Apr 1944, DODA.

1136 SA Armd Div Routine Order no 37 (CMF), 25 Sept 1944, Div Docs, Box 150, vol 2, 6 SA Armd Div Routine Orders and Special Routine Orders, Jan to Dec 1944, DODA.

114 Department of Defence Archives: Div Docs, box 150, vol 2, 6 Armd Div Routine Orders and Special Routine Orders, January to December 1944, 6 SA Armd Div Routine Order no 40 (CMF).

115 WR, Personnel File: JB Lugg no 310599, DODA.

116 JB Lugg Record of Volunteer's Service, WR, Personnel File:JB Lugg, no 310599, DODA.

117 WR, Personnel File:JB Lugg, no 310599, DODA.

118 Orpen, Victory in Italy, pp 24-25; Orpen, Prince Alfred's Guard, p 185.

119 General Mark Clark to Colonel HA Olsen, 24 Dec 1945, WD, box 639, Prince Alfred's Guard, 1 Jan 45 to 31 Jan 1945, DODA.

120 WR, Personnel File: JB Lugg no 310599, DODA.

121 See Div Docs, box 191 for more detail.

122 Releases discharges and compassionate leave, Div Docs, box 183, AQ 18/9 (Vol 7) Releases- closed, DODA.

123 WR, Personnel File: JB Lugg no 310599, DODA.

124 WD, Box 639, Prince Alfred's Guard, 1 Mar 45 to 31 Mar 1945, DODA.

125 Orpen, Prince Alfred's Guard, pp 283-284.

126 Year Book Article (Year Book no 23-1946- Chap xxx), p 30, UWH, box 169, Narep UNFO 24, DODA.

127 WD, box 163, Casualty Returns, 6 SA Armd Div- Battle Casualties \& Battle Accidents, DODA.

128 Van der Waag, A Military History of Modern South Africa, p 212.

129 Lugg, A Natal Family Looks back, pp 81,125-126.

130 Genealogy and social networking search: Harry Lugg

[Retrieved 25 August 2020] https://www.geni.com/people/Harry-Camp-Lugg/6000000010008875071

131 Genealogy and social networking search: Phyllis Lugg

[Retrieved 25 August 2020] https://geni.com/people/Phyllis-Sheila-Lugg/6000000010055772443

132 Genealogy and social networking search: Nancy Lugg

[Retrieved 25 August 2020] https://www.geni.com/people/Nancy-Pennefather/6000000010055596438

133 Genealogy and social networking search: Eric Lugg

https://www.geni.com/people/Eric-Dacre Lugg/6000000010055210775 
134 Genealogy and social networking search:John Lugg

[Retrieved 25 August 2020] https://www.geni.com/people/John-Beresford/6000000010055853344 